ТРЕТМАН НОВОРОЪЕНЧЕТА С АПСТИНЕНЦИЈАЛНИМ

\title{
СИНДРОМОМ
}

Биљана Стојановић Јовановић ${ }^{1}$, Стеван Јовановић $^{2}$

\section{TREATMENT OF NEWBORN WITH NEONATAL ABSTINENCE SYNDROME}

Biljana Stojanović Jovanović, Stevan Jovanović

\section{Сажетак}

Наркотички апстиненцијални синдром новорођенчета (НАС) представља скуп симптома и знакова које испољава новорођенче мајке зависне од наркотика.

Фетални алкохолни синдром (ФАС) испољава новорођенче чија је мајка у току трудноће конзумирала алкохол. Инцидениу самог НАС-а и ФАС-а веома је тешко утврдити због непоузданих података о коришћењу наркотика и алкохола у трудноћи и ограничених могућности дијагностиковања пренаталне изложености новорођенчета наркотицима и алкохолу. Реч је о мултисистемском поремећају који најчешће укључује ичентрални нервни и гастроинтестинални систем и исказује се појавом иритабилности, дуготрајног плача високог тоналитета, тремором, конвулзијама, поремећајима храњења и спавања, тахипнејом, апнејом, тахикардијом, термолабилношћу и знојењем, учесталим штуиањем, зевањем и кијањем, дијарејом, повраћањем и дехидрачијом.

Циь рада је да се увидом у доступну литературу изврии ревијални преглед и укаже на потребе за негом новорођенчета с овим проблемом у првих 48-72 сата живота када се најчешће и испољава клиничка слика.

Мере подрике подразумевају боравак детета у замраченој, тихој средини како би се смағила сензорна стимулација и иритабилност, чести мали оброчии хиперкалоријске формуле да би се покриле додатне калоријске потребе, као и стална опсервачија

\section{Summary}

Narcotic neonatal abstinence syndrome (NAS) is a collection of signs and symptoms exhibited by a newborn mothers of drug addicts.

Fetal alcohol syndrome (FAS) exhibits a newborn whose mother during pregnancy, alcohol consumed. The incidence of NAS and FAS is very difficult to determine because of unreliable data on the use of drugs and alcohol during pregnancy and limited diagnostic prenatal exposure to drugs and alcohol newborn. It is a multisystem disorder, most frequently involving central nervous and gastrointestinal system, which is expressed irritability, prolonged high-pitched cry, tremors, convulsions, feeding and sleeping disorders, tachypnea, apnea, tachycardia, termolability and sweating, frequent hiccups, yawning and sneezing, diarrhea, vomiting and dehydration.

The aim is that it is examining the available literature make a show review and draw attention to the need for care, the newborn with this problem in the first 48-72 hours of life when most often manifested clinical picture.

Support measures include the child in the room darkened room to reduce sensory stimulation and irritability, frequent small meals hiperkalorijske formula to cover the additional caloric requirements, and constant observation of the rhythm of sleeping habits, gain or loss in body weight and change in clinical status, which might suggest another disease process. In these situations, it is necessary to encourage breast-feeding as the best nutrition with all its advantages, including encouraging

\footnotetext{
${ }^{1}$ Мр сц. мед. Биљана Стојановић Јовановић, Висока здравствена школа струковних студија у Београду, Цара Душана 254, Београд.

${ }^{2} \mathrm{Mp}$ сц. Стеван Јовановић, магистар наука мултидисциплинарних научних области - неуронауке, Висока здравствена школа струковних студија у Београду, Цара Душана 254, Београд
} 
ритма спавања, термостабилности, добијања или губљења у телесној маси, као и промене у клиничком статусу које би могле указивати и на друге патолошке прочесе. У овим ситуацијама треба подстицати дојење као најбољи начин исхране са свим својим предностима, укључујући и подстицање емотивне везе између мајке и детета, али контраиндиковано је ако мајка и даље користи наркотике, алкохол или има инфекичје попут HIV-а или хепатитиса.

Уживањем наркотика, алкохола и других супстанции током трудноће, будуће мајке излажу своју деиу ризику од превременог рађања,инфекиијехепатитисомБилиЦ,НІV инфекцији, конгениталним аномалијама, когнитивним поремећајема, итд. Један од кључних задатака здравствених радника јесте рад на превенцији: правовременој едукаиији и саветовању гравидних жена са проблемом зависности.

Кључне речи: апстиненщијални синдром новорођенчета, новорођенче, злоупотреба наркотика, алкохол, конвулзије, нега. emotional bond between mother and child or contraindicated if the mother continues to use drugs, alcohol or have infections such as HIV or hepatitis.

The consumption of drugs, alcohol and other substance use during pregnancy, expectant mothers expose their children to the risk of premature birth, infection with hepatitis $B$ or $C$, HIV infection, congenital anomalies, cognitive poremećajema etc. One of the key tasks of health workers to work on prevention: timely education and counseling of pregnant women with addiction problems.

Key words: neonatal abstinence syndrome, newborn, abuse narcotic, alcohol, convulsions, care.

\section{УВОД}

$\mathrm{H}$ аркотички апстиненцијални синдром новорођенчета представља скуп симптома и знакова које испољава новорођенче мајке зависне од наркотика. Фетални алкохолни синдром испољава новорођенче чија је мајка у току трудноће конзумирала алкохол. ${ }^{(1)}$ Инциденцу наркотичког апстиненцијалног синдрома и феталног алкохолног синдрома новорођенчета је веома тешко утврдити због непоузданих података о коришћењу наркотика и алкохола у трудноћи, као и ограничених могућности дијагностиковања пренаталне изложености новорођенчета наркотицима и алкохолу. ${ }^{(1,2)}$ Као и у свим аспектима здравствене неге, нега новорођенчета са неонаталном наркоманијом треба да буде предвиђена на неосуђујући начин, посебно због тога што је новорођенче невина жртва злоупотребе супстанци од стране друге особе. ${ }^{(1)}$ Употреба психоактивних супстанција током трудноће има вишеструко негативан утицај на здравље труднице и плода. Ток и исход трудноће су често праћени многим компликацијама.

Свака психоактивна супстанција коришћена током трудноће пролази трансплацентарно до фетуса. ${ }^{(2)}$ Рођењем долази до наглог прекида трансплаценталног дотока наркотика, уз истовремено настављање његовог метаболисања и екскреције од стране новорођенчета, што доводи до рапидног смањења концентрације наркотика у дететовом организму са консекутивним испољавањем апстиненцијалног синдрома новорођенчета. ${ }^{(3)}$ Новорођенче мајке уживаоца психоактивних супстанција јесте оно чија је мајка током трудноће узимала психоактивне супстанције које могу да изазову неонатални апстиненцијални син- 
дром. Скуп симптома и знакова код неонатуса удружених са наглим прекидом дотока претходно наведених супстанција је неонатални апстиненцијални синдром. ${ }^{(4)}$

\section{ЦИЉ РАДА}

Циљ рада је да се увидом у доступну литературу изврши ревијални преглед написаних текстова и укаже на потребе за негом новорођенчета с овим проблемом у првих 48-72 сата живота када се и најчешће и испољава клиничка слика.

\section{МЕТОД}

Доступна литература прегледана је претраживањем електронских база података (EBSCO Medline, EBSCO host, Science Direkt, ProQuest) које су доступне преко Конзорцијума библиотека Србије за обједињену набавку (KoBSON).

\section{ПРЕГЛЕД ЛИТЕРАТУРЕ}

Према истраживању Европске агенције за реконструкцију о злоупотреби дроге, у Србији највероватније има око 100.000 наркомана, а скоро 11\% становника Србије пробало је бар некад неку дрогу, у 99\% случајева марихуану. Неонатални апстиненцијални синдром јавља се код око $60 \%$ свих фетуса изложених наркотицима. ${ }^{(5)}$ Уз саме наркотичке супстанце, на ток и исход трудноће утичу и стања често придружена начину живота зависника: низак социоекономски стандард мајке, лоша пренатална нега, адолесцентни узраст мајке, брачни статус мајке (често невенчане), преносиве болести, малнутриција, лоша пренатална контрола. ${ }^{(6)}$

Дијагноза није једноставна. Може да се постави на основу анамнезе мајке, али она је често непоуздана јер већина корисника психоактивних супстанци не признаје њихову употребу или минимизира коришћења наркотика током трудноће, па су подаци о учесталости узимања, врсти супстанци, удруженом узимању алкохола и дувана, веома непоуздани. ${ }^{(7)}$

\section{Индикатори ризика за интраутерину експозицију новорођенчета наркотицима}

Индикатори ризика за интраутерину експозицију новорођенчета наркотицима могу да буду од стране мајке и саме карактристике плода. ${ }^{(5)}$

Од стране мајке подаци о коришћењу дрога у овој или претходним трудноћама, подаци о партнеру - кориснику наркотика, бескућништво, претходна деца стављена под социјално старање, нагле изразите промене расположења, претходне необјашњиве интраутерине смрти плода, цереброваскуларни акциденти, одсуство или недовољна пренатална контрола, подаци о хепатитису B, AIDS-y, сифилису, гонореји, проституцији мајке, необјашњива абрупција плаценте, необјашњив превремени порођај.

Карактеристике детета које се могу повезати са мајчиним коришћењем наркотика су прематуритет, необјашњива интраутерина ретардација раста, неуробихејвиоралне абнормалности, атипични васкуларни и други инциденти код детета попут цереброваскуларних крварења, некротични ентероколитис код иначе здравог терминског детета, необјашњиве конвулзије или апнее, клинички симптоми и знаци неонаталног апстиненцијалног синдрома (хипертонија, иритабилност, конвулзије, тремулације, мишићна ригидност, дијареја). ${ }^{(5,7,8)}$

\section{Материјал који се узима за лаборатотијске тестове}

Урин, мајчин и дететов, показује присуство психоактивних супстанција до три дана после рођења. Меконијум показује присуство психоактивних супстанција до три дана после рођења и већа је вероватноћа да ће идентификовати ову децу него анализа урина, но тест је знатно скупљи и мање доступан. ${ }^{7)}$ Коса - најсензитивнији и најскупљи тест, показује конзумирање 
психоактивних супстанција у последњем триместру трудноће. Коса расте 1-2cm месечно, те мајчина коса може бити сегментирана, сваки сегмент анализиран. $\left.{ }^{(9,}{ }^{10}\right)$ Овај метод је скуп и доступан само у великим центрима; метаболити разних супстанци могу се детектовати и из дететове длаке 2-3 месеца након рођења, али може „промашити” скорашње узимање наркотика јер је раст длаке спор. ${ }^{(5,11)}$

Новорођеначки апстиненцијални синдромизазивајуибројнилекови: барбитурати, бензодиазепини, антидепресиви итд., који се користе током трудноће у медицинске сврхе, као и њихове злоупотребе током трудноће. (7, 12) Неонатални апстиненцијални синдром изазива неуролошке, гастроинтестиналне и/или респираторне поремећаје код новорођенчета уколико је оно пренатално било изложено деловању психоактивних супстанци. ${ }^{(12)}$

Према прегледаној литератури, симптоми и знаци код детета које је родила мајка корисник психоактивних супстанција личе на оне који се јављају код апстиненцијалног синдрома одраслих и укључују хиперактивност ЦНС-а, плач високог тоналитета, тремор, конвулзије, поремећај храњења и спавања, повишен мишићни тонус и повишен Моров рефлекс, тахипнеу и апнеу, тахикардију, регургитацију и повраћање, термолабилност и знојење, дијареју и повраћање, кијање и запушеност носа, штуцање, сузење ока, ненапредовање у телелесној маси, ${ }^{(2,13)}$ превремено рођење, интраутерини застој раста, микроцефалију, повећану инциденцу конгениталних аномалија (срчане мане, генитоуринарне аномалије, расцеп непца, билијарна атрезија. ${ }^{(3,}$ $14,15,16)$

Новорођенчад рођена из трудноће у току које је мајка конзумирала опијате показује знаке и симптоме неонаталног апстиненцијалног синдрома у 60-90\% случајева и они се појављују непосредно након рођења или 1-2 недеље одложено што зависи од врсте наркотика који је мајка користила, али могу бити одложени и до 4 недеље узраста. Субакутни знаци неонаталног апстиненцијалног синдрома могу да постоје и до узраста од 6 месеци. ${ }^{(2,7)}$ Многе студије наводе да озбиљност манифестације неонаталног апстиненцијалног синдрома по својој тежини и времену испољавања зависи од разних фактора: врсте наркотичке супстанце, њене дозе, учесталости узимања, последње интраутерине експозиције плода, мајчиног али и дететовог метаболизма и екскреције наркотика и његових метаболита. ${ }^{(11,}$ $17,18,19)$

Према прегледаној литератури и алкохол је чест изазивач апстиненцијалног синдрома код новорођенчета. Алкохол пролази постељицу и смањује њену функцију. Новорођенче чија је мајка у току трудноће конзумирала алкохол може да има фетални алкохолни синдром, и то код $35-40 \%$ новорођенчади. ${ }^{(4)}$ При злоупотреби алкохола у трудноћи постоји висок ризик од конгениталних аномалија и сниженог коефицијента интелигенције. Доказано је да је алкохол данас главни узрок конгениталне менталне ретардације.

Клиничка слика феталног алкохолног синдрома обухвата: пренаталну и постнаталну ретардацију раста плода, иритабилност ЦНС-а, хиперактивност у детињству, успорен развој, хипотонију, снижену интелигенцију, микроцефалију, микрофталмус, хипопластичну максилу итд. Абдоминална дистензија и повраћање код деце са ФАС-ом мање су изражени него што је то случај код деце са НАС-ом насталим злоупотребом других психоактивних супстанција. ${ }^{(2)}$

\section{НЕПОСРЕДНЕ ИНТЕРВЕНЦИЈЕ МЕДИЦИНСКЕ СЕСТРЕ КОД НОВОРОБЕНЧЕТА С АПСТИНЕНЦИЈАЛНИМ СИНДРОМОМ}

Новорођенче се смешта у инкубатор, дечји креветац, колевку. На кратко може 
да лежи на столу за реанимацију, столу за загревање или на пулту. Изолета поред контроле температуре новорођенчета обезбеђује и изолацију, као и приступне отворе за инфузију, сукцију, кисеоник, контролу телесне масе итд. ${ }^{(1)}$ Положај кревета где новорођенче борави треба да буде такав да омогући медицинској сестри - бабици и другом особљу прегледност, а од виталне важности је и да сва опрема буде у стању приправности и у потпуности комплетирана, јер у случају потребе за реанимацијом новорођенчета нема времена за тражење, проверу исправности или пак склапање и комплетирање неопходне опреме. $^{(1)}$ На кревецу треба да постоје ограде које се могу спуштати, са вертикално постављеним шипкама, што омогућава боље струјање ваздуха око детета, а и ради лакшег посматрања детета из непосредне близине. Страница изнад главе пацијента такође треба да буде покретна, ради лакшег приступа пацијенту. Сви рубови треба да буду обли. ${ }^{(1,20)}$

Раздвајање мајке и детета носи опасност и потребно је да буде избегавано, сем ако је апсолутно неопходно. Простор треба да буде оплемењен. Стога, треба дозволити и охрабрити родитеље да украсе простор личним предметима донетим од куће, плишаним играчкама, прекривачем, сликама породице. ${ }^{(21)}$ Када је реч о времену пружања неге, размотрити циклус спавања и будности детета, његове енергије за храњење и периоде тихе будности када је само мирно. Новорођенчету обезбедити мрак током спавања и одржавати слабо пригушено светло у свако доба да би се подстакла будност детета. Уверити се да светло које пада на лице детета није директно. А, ако је индикована фототерапија код детета, уверити се да је прво искључена лампа пре него што су скинуте наочари за очи. ${ }^{(22)}$

Нежно говорити детету и додиривати га да осети присуство сестре и/или мајке и то док се не уверите да је тело детета опуштено. Нежно уклонити заштиту за очи и помазити дете да се опорави од јаког и изненадног излагања јаком светлошћу. Тек након тога, почети са формалном негом. Када је интервенција завршена и пошто се помогло детету да се умири, поново се нежно ставља заштита за очи, помазити дете, сместити га поново у инкубатор, укључити светло и остати поред постеље док се дете не умири. ${ }^{(23)}$ Увек говорити нежним гласом све време, ходати лагано, носити само меку обућу крећући се лагано и нежно, увек затворити врата инкубатора нежно и тихо.

Подстицати особље да говори нежно, уклонити све радио уређаје са гласном музиком, телефоне подесити на најнежније тонове. Пожељно је да примопредаја смене буде мало даље од детета.(24) Одржавати веома смирену, тиху и умирујућу атмосферу све време. Хитне ситуације решавати смирено и тихо. Помоћи и осталима да буду умирени и добродошли у том простору. Помоћи да дете остане мирно и опуштено током процедура и интервенција. Све комуникације запослених уколико нису везане за дете, обављати даље од њега. А што се визуелног распореда тиче, унутар и близу инкубатора и колевке бирати предмете са пажњом који ће бити у видном пољу детета које је у кревецу и /или инкубатору и проценити да ли су умирујући или раздражујући.

Сачувати стимулативне играчке и слике са јарким бојама за време када ће дете бити довољноснажнодауживауњима.Постепено уводити нови визуелни стимуланс само онда када је дете спремно за то. Ублажити и уклонити анимиране визуелне стимулансе из дететевог видног поља када дете постане поспано, узнемирено или скреће поглед. Неорганизовани покрети очију, одвраћање погледа, хипербудност и паничан израз лица су знаци да је дете исувише стимулисано. Не користити парфеме јер делују раздражљиво. Присуство родитељског тела је умирујуће и опуштајуће за дете па треба инсистирати на томе ако се процени да је то 
безбедно за дете. ${ }^{(25)}$ Користити материјале који су меки, удобни, одговарајуће величине, текстуре и облика. Оделца и капице бирати од природних материјала у складу са величином детета, а пожељно је користити водени јастук, гнездо и меке јастуке за грљење. Детету прија нежно њихање у наручју и то му помаже да се смири. Треба му обезбедити максимални угођај и комфоран положај, ослобођен сваког притиска. Када медицинска сестра приступа кревету увек треба да стане тако да види дететово лице. Израз његовог лица говори како се осећа: да ли је узнемирено или је смирено. Када се дете мешкољи и постане немирно поново га подржати да би заспало. Треба бити свестан дететовог стања. Охрабрити родитеље да се ослободе и прихвате негу детета на безбедан начин. ${ }^{(26)}$ Сестра све време треба да буде свесна да је она дететова подршка. Када се дете пробуди погледати га нежним изразом лица и говорити му полако веома нежним гласом уз тихо певање. Када дете гледа јасним погледом и са благим покретима лица, ово указује на задовољство због интеракција. Препоручује се нежно повијање детета са позиционирањем у флексионом положају, као и превенирање и смиривање ексцесивног плача варалицама.

Дојење, као најбољи начин исхране са свим својим предностима, укључујући и подстицање емотивне везе између мајке и детета тако важне у овим ситуацијама, треба подстицати. Контраиндиковано је ако мајка и даље користи наркотике или има инфекције попут HIV-a или хепатитиса. $(5,11)$ Подстицати новорођенче да искључиво доји, и то често, без стриктног поштовања неког задатог режима дојења. Стављање новорођенчета на груди мајке када оно то захтева омогућава пражњење дојки и подстиче брже успостављање лактације. Насупрот томе, у потпуности је искоришћена свака кап млека-колострума, што подиже имунитет детету. Погрешно је у првим данима живота, док се не успостави лактација, и у нормалним околностима, напајати дете заслађеном водом, чајем, или неким адаптираним формулама млека. Таква пракса увећава ризик од инфекције и сензибилизације новорођенчета на протеине крављег млека. Уколико је контраиндиковано дојење, новорођенче напајати и хранити на други начин. ${ }^{(1)}$ Иницијални третман новорођенчета са наркотичким апстиненцијалним синдромом треба да буде примарно симптоматски, с обзиром на то да фармаколошка терапија излаже дете дејству јаких седатива и продужава хоспитализацију. ${ }^{(27)}$

Апстиненцијални синдром новорођенчета је, с обзиром на растући проблем наркоманије у савременом друштву, потенцијално све чешћи у неонатолошкој пракси. Дијагноза није једноставна. Могућност HAC-a треба стално имати у виду како би се пажљивим прикупљањем и проценом релевантних података и клиничких и лабораторијских налаза правовремено утврдио. Збрињавање новорођенчади с апстиненцијалним синдромом треба да диктира клинички налаз, а акценат је на симптоматским мерама. ${ }^{(28)}$ Такав приступ лечењу води ка опоравку новорођенчади с овим проблемима и успостављању једног од основних ритмова по изласку из породилишта, ритма храњења и спавања. ${ }^{(29)}$ Новорођенчад с овим синдромом је веома важно адекватно акутно збринути, али је такође веома важно и дуготрајно праћење њиховог здравственог стања, психомоторичког развоја, као и степена неге и родитељског старања.

Потребно је укључити и социјалну службу, с обзиром на то да је у таквим породицама далеко чешће злостављање и занемаривање деце.(2) Код ове деце постоји повишен ризик од синдрома изненадне смрти одојчета (СИДС-а), абнормалног неурокогнитивног и бихејвиоралног развоја и дефицијентног моторног развоја. У прве две године напредују по принципу catch up феномена. Недостају студије дуготрајног праћења овакве деце, али у узрасту 5-6 
година показују физиолошки ниво менталног и моторичког развоја вршњака. Неки могу да имају поремећаје понашања и социјалне адаптације. ${ }^{(2,32)}$

\section{ЗАКЈУУАК}

Апстиненцијални синдром новорођенчета је сложен и вишеслојан проблем. Смањење његове учесталости и утицаја захтева хитну акцију у циљу побољшања неге угрожених жена и деце. Мајке које су лечени или нелечени зависници често крију податке о узимању недозвољених супстанци или препоручених лекова у циљу лечења зависности, те се тачан податак о броју деце рођене од мајки зависника и не зна. Лекари често тек након порођаја, и то на основу знакова апстиненцијске кризе бебе, која је видљива по тешким грчевима, непрестаном плачу и презнојавању, схвате да пред собом имају бебу зависника. У Србији из године у годину је све већи број беба које се рађају с апстиненцијалним шоком, јер су им мајке тешки зависници од хероина, кокаина, морфијума, тродона, алкохола итд. Новорођенчад мајки зависница углавном се рађају пре времена, имају мању килажу, дезоријентисана су и с успореним виталним функцијама. Одмах по рођењу таква новорођенчад се смештају у инкубатор, а након 24 сата, када се потврди да новорођенче има синдром апстиненцијалног шока, супортивне мере подразумевају боравак детета у замраченој, тихој средини како би се смањила сензорна стимулација и иритабилност, чести мали оброци хиперкалоријске формуле да би се покриле додатне калоријске потребе, као и стална опсервација ритма спавања, термостабилности, добијања или губљења у телесној маси, као и промене у клиничком стању. Због вишеструке медицинске и психосоцијалне потребе мајки и новорођенчади са наркотичним апстиненцијалним синдромом неопходно је пажљиво планирање примарне здравствене заштите и психосоцијалне подршке породицама. Деца су примарна брига, она су под ризиком и треба да постоји едукација мајки, партнера и породице од стране стручног особља. Да би се избегле празнине у нези и праћењу деце с овим проблемом, на рођењу су ове клиничке смернице важне са циљем промовисања сигурне и ефикасне неге.

\section{ЛИТЕРАТУРА}

1. Маринковић Љ, Стојановић Б, Дамјанчевић Н. Нега неонатуса, ВЗШСС. Београд, 2013.

2. Радуновић-Гојковић T, ВелисављевФилиповић Г. Апстиненцијални синдром код новорођенчета - приказ случаја. Мед Преглед. Нови Сад, 2009; LXII(3-4): 181-184.

3. Bada HS, Bauer CR, Shankaran S, Lester B, Wright LL, Das A, et al. Central and Autonomic System signs With in utero Drug Exposure. Archives of Disease in Childhood Fetal and Neonatal Edition, 2002; 87: 106-12.

4. Alpan G. Infant of a Drug-Abusing Mother. In: Gomella TL, Cunningham MD, Eyal FG, Zenk KE, eds. Neonatology:
Management, Procedures, On-Call

Problems, Diseases, and Drugs. 5th ed. New York: Lange Medical Books/McGraw Hill, 2004; 424-33.

5. Матић А. Апстиненцијални синдром новорођенчета. Acta Medica Medianae, 2008; 47(1): 55-59.

6. Savitz DA, Henderson L, Dole N, Herring A, Wilkins DG, Rollins D, Thorp JM Jr. Indicators of Cocaine Exposure and Preterm Birth. Obstet Gynecol, 2002; 99: 458-65.

7. American Academy of Pediatrics:

Neonatal Drug Withdrawal. Pediatrics, 1998; 101(6): 1079-88.

8. Wolff K, Boys A, Rostami-Hodjegan

A, et al. Changes to Methadone Clearance 
during Pregnancy. Eur J Clin Pharmacol, 2005; 61: 763-768.

9. Ostrea EM, et al. Estimates of Ilicit Drug Use During Pregnancy by Maternal Interview, Hair Analysis, and Meconium Analysis. J Pediatr, 2001; 138: 344.

10. Jackson L. Handling Drug Misuse in the Neonatal Unit. Infant. 2006; 2(2): 64-7.

11. Belik J, Hawes J. Neonatal Abstinence

Syndrome. Emedicine, 2006. - електронско издање (преузето децембар 2015).

Доступно на (http://www.emedicine.com/ ped/topic2760.htm).

12. Јанковић Б. Неонатални апстиненцијални синдром. У: Јанковић Б, Константинидис Г, Лозановић Д, Бранковић Д, Аврамовић Л, Тодоровић Н, и сар. Водич за основно и специјализовано збрињавање новорођенчета. Институт за здравствену заштиту мајке и детета Србије „Др Вукан Чупић”, Београд, 2011; 179-84.

13. Siu A, Robinson CA. Neonatal Abstinence Syndrome: Essentials for the Practitioner. J Pediatr Pharmacol Ther, 2014; 19(3): 147-55.

14. Kwong TC, Ryan RM. Detection of Intrauterine Illicit Drug Exposure by Newborn Drug Testing. Clinical Chemistry, 1997; 43: 235-42.

15. Newborns With Fetal Cocaine Exposure. Pediatrics, 2001; 107(5): 74.

16. Kelly RH, Russo J, Holt VL, Danielsen BH, Zatzick DF, Walker E, Katon W.

Psychiatric and Substance Use Disorders as Risk Factors for Low Birth Weight and Preterm Delivery. Obstetrics \& Gynecology, 2002; 100: 297-304.

17. Jansson LM, Dipietro JA, Elko A, et al. Maternal Vagal Tone Change in Response to Methadone is Associated with Neonatal Abstinence Syndrome Severity in Exposed Neonates. J Matern Fetal Neonatal Med, 2007; 20: 677-685.

18. Jansson LM. Academy of Breastfeeding Medicine Protocol Committee. ABM
Clinical Protocol \#21: Guidelines for Breastfeeding and the Drugdependent Woman. Breastfeed Med, 2009; 4: 225-228.

19. Seligman NS, Salva N, Hayes EJ, et al. Predicting Length of Treatment for Neonatal Abstinence Syndrome in MethadoneExposed Neonates. Am J Obstet Gynecol, 2008; 199: 396, e391-396 e397.

20. Patrick SW et al. Neonatal Abstinence Syndrome and Associated Health Care Expenditures, United States, 2000-2009; JAMA, 2012; 307(18).

21. Verklan MT, Walden M. Core Curriculum for Neonatal Intensive Care Nursing 4th edition.

22. Marcellus L. Care of SubstanceExposed Infants: the Current State of Practice in Canadian Hospitals. J Perinat Neonatal Nurs, 2002 Dec; 16(3): 51-68.

23. Queensland Maternity and Neonatal Clinical Guideline: Neonatal Abstinence Syndrome MN - преузето у јануару 2016, доступно на: Guidelines@health.qld.gov.au.

24. Oei J, Lui K. Management of the Newborn Infant Affected by Maternal Episodes and Other Drugs in Pregnancy. Journ Ped \& Child Health, 2007; 43: 9-18. 25. Murphy-Oikonen J, Montelpare, Southon S, Bertoldo L, Persichino N. Identifying Infants at Risk for Neonatal Abstinence Syndrome. Journal of Perinatal Neonatal Nursing Vol. 24, No. 4: 366-372. 26. O'Grady MJ, et al. Management of Neonatal Abstinence Syndrome: a National Survey and Review of Practice. Arch Dis Child Fetal Neonatal Ed, 2009; 94: F249-52.

27. Gomella TL, Cunningham MD, Eyal FG, Zenk KE. Neonatology: Management, Procedures, On-Call Problems, Diseases and Drugs. New York, 2004; 424-33.

28. Wang M. Perinatal Drug Abuse and Neonatal Drug Withdrawal. E-medicine, 2004 - електронско издање, преузето јануар 2015, доступно на (http://www. emedicine.com/ped/topic2631.htm). 
29. Lazić Mitrović T. et al. Neonatal Abstinence Syndrome - Diagnostic

Dilemmas in the Maternity Ward. Srp Arh

Celok Lek, 2015 Sep-Oct; 143(9-10): 573577.

30. Frank DA, Augustyn M, Grant Knight W, Pell T, Zuckerman B. Growth,
Development, and Behavior in Early Childhood Following Prenatal Cocaine Exposure. JAMA, 2001; 285: 1613-25. 31. Singer LT, et al. Cognitive and Motor Outcomes of Cocaine-Exposed Infants. JAMA, 2002; 287: 1952.

Контакт: Биљана Н. Стојановић-Јовановић, Висока здравствена школа струковних студија Земун, тел: 011 2618024, адреса: Ул. Дринчићева 11a/66, 11000 Београд, моб. тел: 0691910 884, е-мail: biljananstojanovic@gmail.com 